\title{
Boko Haram and the child's right to education in Africa: Examining the accountability of non-state armed groups
}

\section{Seun Solomon Bakare}

Researcher and doctoral candidate, Grotius Centre for International Legal Studies, Leiden University School of Law, The Netherlands

\begin{abstract}
Summary
This article discusses the accountability debate surrounding the activities of non-state actors and its impact on the realisation of the child's right to education. It examines the legal framework for the protection of the right to education during emergencies and armed conflicts. The article focuses on Boko Haram as an example of a non-state armed group. In this respect, it considers the sect's history and its ideological beliefs, and shows that its activities are a result of its ideologies. It delves into the accountability debate and suggests various approaches towards holding faceless armed groups accountable for rights violations, generally, and the violation of the child's right to education, in particular.
\end{abstract}

Key words: accountability; non-state actors; children's rights; armed conflict; armed groups; education; Boko Haram

LLB (Obafemi Awolowo) LLM (Human Rights and Democratisation in Africa) (Pretoria); s.s.bakare@law.leidenuniv.nl. This article is substantially based on the author's LLM dissertation written at the School of Law, University of Venda, under the supervision of Prof GNK Vukor-Quarshie and Ms Puleng Letuka, and submitted to the Centre for Human Rights, Faculty of Law, University of Pretoria. Errors and omissions are entirely mine. 


\section{Introduction}

The accountability debate in respect of non-state armed groups has been a regular feature of international law, since it was observed that the nature of warfare has gradually changed from the previous understanding that warfare implies a military engagement between two or more states, to a more modern view that involves the participation of non-state armed groups, mostly in intra-state armed conflicts. ${ }^{1}$ This change in the nature of warfare has accounted partly for the increased call to strengthen existing legal and institutional frameworks towards ensuring the accountability of non-state armed groups for rights violations, in general, and the violation of the child's right to education, in particular. A peculiar and rather disturbing feature of this change in warfare is the deliberate targeting of

1 Odermatt 'New wars and the international/non-international armed conflict dichotomy' http://www.isisc.org/dms/images/stories/PDF/Paper\%20Odermatt. pdf (accessed 7 August 2014). In conventional wars, the combatants are identifiable, and there probably is a battlefield or territory, direction, and goals for engaging in the war. Their intentions are often clear-cut and understood by both parties. In the case of this 'asymmetric warfare', however, the same cannot be said. Combatants attack places that are not necessarily warzones and places of learning are fast becoming their primary targets. In $\mathrm{M}$ Kaldor New and old wars: Organised violence in a global era (1999), it is generally argued that a new type of organised violence has surfaced in the period between the 1980s and the 1990s. The author describes these as the 'new wars' and submits that a major distinguishing factor between the new wars and the old wars is that the boundaries between wars that involve states, on the one hand, and organised crimes, which usually involve private or non-state actors, on the other, has become blurred. In essence, she argues that war no longer is an affair conducted solely between states, and that a major factor responsible for the shift in this understanding is globalisation. See also, generally, S Kalyvas "New" and "old" civil wars: A valid distinction?' (2001) 54 World Politics 99; I Hermann \& D Palmieri 'Les nouveux conflits: Une modernité archaïque?' (2003) 85 International Review of the Red Cross 849. See also L Reydams 'A la guerre comme à la guerre: Patterns of armed conflict, humanitarian law responses and new challenges' (2006) 88 International Review of the Red Cross 864, who argues that 'guerrilla-terrorist wars [will] determine the course of violence in the twenty-first century in many parts of the world'. The other change that is easily noticeable is how difficult it has become to classify conflicts into strict categories of international and noninternational armed conflict. Eg, while the Boko Haram sect is primarily involved in attacking targets within Nigeria, it has on several occasions made incursions into Chad, Cameroon, Niger and Benin where it has been alleged that the sect maintains training camps for its combatants. There are also allegations of logistical and financial support for the group by neighbouring state actors. The challenge, therefore, is how to properly classify the armed conflict into international or noninternational armed conflict, considering that there is unclear involvement of 'state actors' on either side. See generally http://www.economist.com/news/ middle-east-and-africa/21608808-boko-haram-thrives-weakness-governments-reg ion-lake (accessed 7 August 2014). In C Bassiouni 'The new wars and the crisis of compliance with the law of armed conflict by non-state actors' (2008) 98 Journal of Criminal Law and Criminology 748, the author argues that the conflict in Rwanda and in the Great Lakes area of Africa, including the Congo and Uganda, are characterized as internal ethnic and tribal warfare, notwithstanding the involvement of combatants from several states'. 
civilians $^{2}$ by armed groups. This was again emphasised in 2014 when the Boko Haram sect ${ }^{3}$ abducted more than 230 young girls from their school hostel in the town of Chibok in Northern Nigeria. ${ }^{4}$ In February 2018 the same sect abducted more than 100 schoolgirls from Dapchi, another town in Northern Nigeria. ${ }^{5}$

The article examines the accountability debate regarding non-state armed groups, considering that the renewed attacks on education and educational facilities around the globe necessitate a reexamination of the debate. Scholars generally concur that there is no agreement on a clear approach towards bringing such groups to accountability under the present frameworks in international law. ${ }^{6}$ The article discusses approaches towards engaging armed groups in line with human rights and humanitarian norms and standards. It focuses on Boko Haram as a classic example of a non-state armed group with a peculiar emphasis on its activities, which constitute direct violations of the right to education. The article begins with a brief overview of the legal frameworks on the child's right to education and its protection during armed conflict. It thereafter focuses on Boko Haram: its origins, ideologies, activities and impact on the child's right to education. Further, it discusses the need for strengthening existing frameworks as well as recommendations on the necessity of actively engaging armed groups within the boundaries of international human rights and humanitarian law.

\section{Overview of the legal framework on the right to education and its protection during armed conflict}

In international law, the collective body of laws that governs armed

2 G) Andreopolous 'On the accountability of non-state armed groups' in G) Andreopolous et al (eds) Non-state actors in the human rights universe (2006) 141.

3 Boko Haram is the popular media appellation for a Nigerian armed group known as Jama'atul Alhul Sunnah Lidda'wati wal Jihad, or 'People Committed to the Propagation of the Prophet's Teachings and Jihad'. Boko Haram as an appellation translates literally to 'Western education is forbidden' and this is a pointer to the ideology that propels the group into action. In the US House of Representative's Committee on Homeland Security's 'Boko Haram: Growing threat to the US homeland' (2013) http://homeland.house.gov/sites/homeland.house.gov/files/ documents/09-13-13-Boko-Haram-Report.pdf (accessed 8 November 2014), the report identifies how the group has gone through several phases of change in addition to the emergence of splinter groups which have become more radical and violent.

4 'Chibok abductions in Nigeria: "More than 230 seized"' BBC News http:// www.bbc.com/news/world-africa-27101714 (accessed 8 November 2014).

5 S Busari \& B Adebayo 'Most of kidnapped schoolgirls freed, Nigeria says' https:// edition.cnn.com/2018/03/21/africa/nigeria-kidnapped-girls-boko-haram-intl/ index.html (accessed 30 April 2018).

6 A Clapham Human rights obligations of non-state actors (2006). 
conflicts are international human rights law, $^{7}$ international humanitarian $\operatorname{law}^{8}$ and international criminal law. ${ }^{9}$ While these laws differ in certain respects, they share 'the goal of preserving the dignity and humanity of all', ${ }^{10}$ while at the same time seeking to punish the violators of human rights. Before recent developments under international law, it was erroneously believed that international human rights law applied only in times of peace and for the regulation of the relationship between states and their nationals, while international humanitarian law applied only in times of war and concerns the treatment of combatants and non-combatants by the other party to a conflict. In this respect, international human rights law did not seem to accommodate any notion of loss of life, as the sanctity of life and the guarantee of the right to life were considered the most important requirements for the enjoyment of other rights. ${ }^{11}$ International humanitarian law, for its part, was known to consist of norms that regulated the loss of the lives of combatants and, to a certain extent, it provided for and envisaged the loss of lives of noncombatants or 'civilian casualties [as] lawful collateral damage'.12 These erroneous views have been abandoned, and currently it is firmly established that international human rights law also applies in situations of armed conflict. ${ }^{13}$ A recent example is the jurisprudence of the International Court of Justice (ICJ), which reads that 'the protection of ICCPR does not cease in times of war'. $^{14}$

This body of laws provides three broad categories in which children's rights to education may be challenged. These are instances where children live in conflict zones, where children are internally displaced and where they cross international borders as refugees. ${ }^{15}$

7 It is defined as 'a system of international norms designed to protect and promote human rights of all persons'. See generally UN Doc HR/PUB/11/01 International legal protection of human rights in armed conflict (2011) 5.

8 Sometimes referred to as 'the law of armed conflict', they are a set of rules that seek to limit the effects of armed conflicts, purely on humanitarian grounds. See Clapham (n 6 above).

9 They refer to 'those offences over which international courts or tribunals have been given jurisdiction under general international law. They comprise the socalled 'core' crimes of genocide, crimes against humanity, war crimes and the crime of aggression (also known as the crime against peace).' See generally $\mathrm{R}$ Cryer et al An introduction to international criminal law and procedure (2010) 4. See also D Akande 'Sources of international criminal law' in A Cassese (ed) The Oxford companion to international criminal justice (2009) 41-53.

10 Clapham (n 6 above) 1.

11 It is for this reason that proponents of human rights and international human rights law often campaign and argue for the abolition of the death penalty.

12 Andreopolous (n 2 above) 143.

13 Clapham (n 6 above) 5. See generally L Doswald-Beck \& S Vité 'International humanitarian law and human rights law' (1993) 33 International Review of the Red Cross 94. See also C Droege 'The interplay between international humanitarian law and international human rights law in situations of armed conflict' (2007) 40 Israel Law Review 310.

14 'The legality of the threat or use of nuclear weapons' International Court of Justice, advisory opinion, 1996 ICJ Reports 226 para 25.

15 P Hyll-Larsen The right to education for children in violent conflict (2010). 
However, the article concerns itself with the first and second categories, namely, children who live in conflict zones and those displaced as a result of armed conflict. ${ }^{16}$ According to the Committee on Economic, Social and Cultural Rights (ESCR Committee), the right to education 'has a minimum core content that applies even in insecurity and armed conflict ${ }^{\prime 17}$ and, as such, conflict is not a ground for state parties to derogate from their obligations to protect education and educational facilities. ${ }^{18}$ The United Nations (UN) Committee on the Rights of the Child affirmed this position during its Day of General Discussion on the Right of the Child to Education in Emergency Situations'. ${ }^{19}$ This flows from an understanding that the right to education is a fundamental or basic right ${ }^{20}$ as it is also an empowerment right. ${ }^{21}$ As a result of its primary nature, parties to a conflict owe a duty to preserve and respect education during armed conflict. It is not in doubt that non-state armed groups also have an obligation to respect human rights ${ }^{22}$ as 'all parties to a noninternational armed conflict, including non-state armed groups, must respect and ensure respect for the rules of international humanitarian ${ }_{\text {law }}{ }^{23}$ and, by extension, other legal obligations. These obligations are codified in international and regional instruments and they are

16 As a result of the Boko Haram conflict in Northern Nigeria, the Nigerian Emergency Management Authority (NEMA) has said that more than 400000 people, most of them children, have been displaced since the beginning of fresh hostilities. See ' 400000 persons displaced by Boko Haram says NEMA' The Punch 14 August 2014 8. See also 'Internal displacement in Nigeria worst ever - UN' The Punch 5 October 2014.

17 In its General Discussion Day, the ESCR Committee points out that the ICESCR identifies the 'minimum core content of the right to education protected at all times and of immediate application'. A fundamental obligation of this core content is states' duty 'to ensure free choice of education without interference from the state or third parties'. See generally 'General Discussion Day: The right to education (articles 13 and 14 of the Covenant)' UN Doc E/C.12/1998/SR.49, 2 December 1998 and General Comment 13 of the ESCR Committee.

18 An examination of the CRC reveals that the Convention is the first international instrument to incorporate the rules of international humanitarian law and international human rights law in one single document and does not allow for derogation in times of conflict. See generally C Hamilton \& T El-Haj 'Armed conflict: The protection of children under international law' (1997) 5 International Journal of Children's Rights 1 . The African Charter, unlike other international human rights instruments, contains no derogation clause and sufficiently shows that parties cannot derogate from their obligations to provide and protect education, even in situations of emergency or armed conflict.

19 49th session held from 15 September to 3 October 2008.

20 F Veriava 'The right to education' in D Brand et al (eds) Socio-economic rights in South Africa (2005) 57.

21 F Coomans 'The core content of the right to education' in D Brand \& S Russell (eds) Exploring the core content of socio-economic rights: South African and international perspectives 182.

22 A Cassese 'The status of rebels under the 1977 Geneva Protocol on NonInternational Armed Conflict' (1981) 30 International and Comparative Law Quarterly 424; see also UNSC Resolution 1214 (1998), 8 December 1998 para 12.

23 T Pfanner 'Various mechanisms and approaches for implementing international humanitarian law and protecting and assisting war victims' (2009) 874 International Review of the Red Cross 279 281. See also K Hausler et al Protecting education in insecurity and armed conflict: An international law handbook (2012) 44. 
generally known as international and regional frameworks for the protection of human rights, particularly the right to education, during armed conflict.

The next sections first examine the general provisions on the right to education and, thereafter, discuss the specific provisions that relate to the protection of education during armed conflict.

\subsection{International legal frameworks}

In a general sense, the right to education is guaranteed in the Universal Declaration of Human Rights (Universal Declaration), ${ }^{24}$ the Convention Against Discrimination in Education, ${ }^{25}$ as well as the International Covenant on Economic, Social and Cultural Rights (ICESCR). ${ }^{26}$ In a more specific sense, however, the right is guaranteed for certain vulnerable groups in instruments that are group-specific. These include the Convention on the Right of the Child (CRC); ${ }^{27}$ the Optional Protocol to the CRC on Children in Armed Conflict (OPAC); ${ }^{28}$ the Convention on the Elimination of All Forms of Discrimination Against Women (CEDAW); ${ }^{29}$ and the Convention on the Rights of Persons with Disabilities (CRPD). ${ }^{30}$

Additionally, the Fourth Geneva Convention Relative to the Protection of Civilian Persons in Times of War of 1949 and its two additional Protocols of 1977, the Rome Statute of the International Criminal Court (ICC) of 1998, as well as the International Labour Organization (ILO) Convention 182 on Child Labour of 1999 are relevant for the protection of education and the preservation of places of learning during armed conflict and emergencies.

\subsubsection{General provisions on the right to education}

Although non-binding, the Universal Declaration is the source of inspiration for most post-World War II international instruments within the UN mechanism. ${ }^{31}$ It lays the template ${ }^{32}$ and serves as guiding principles for many other subsequent instruments that include binding provisions on the right to education. Article 26 places the right to education at the forefront of the promotion and protection of

24 Adopted by UN General Assembly on 10 December 1948.

25 Adopted in Paris by the General Conference of UNESCO on 14 December 1960.

26 Alongside the ICCPR, the UN General Assembly adopted it on 16 December 1966.

27 Adopted by the UN General Assembly in 1989.

28 Adopted and opened for signature, ratification and accession by the UN General Assembly Resolution A/RES/54/263 of 25 May 2000. It entered into force on 12 February 2002.

29 Adopted by UN General Assembly in 1979.

30 Adopted by UN General Assembly on 13 December 2006.

31 Vienna Declaration and Programme of Action para 8. The World Conference on Human Rights adopted the Vienna Declaration on 25 June 1993 in Vienna, Austria.

32 J Dada 'Human rights under the Nigerian Constitution: Issues and problems' (2012) 2 International Journal of Humanities and Social Science 12. 
other rights. Not only does it provide that 'everyone has the right to education', 33 but it further provides that 'education shall be directed to the full development of the human personality and to the strengthening of respect for human rights and fundamental freedoms'. ${ }^{34}$ Subsequent instruments on the right to education at the international and regional levels have drawn inspiration from these provisions in the Universal Declaration. One such instrument is the Convention Against Discrimination in Education, which generally seeks to promote the right to education for all, and to ensure that there is no discrimination in its provision and availability. ${ }^{35}$

It has also been argued that the Universal Declaration played a vital role in the adoption of the two covenants of 1966; the International Convention on Civil and Political Rights (ICCPR) and the ICESCR. ${ }^{36}$ Article 13 of the ICESCR, which extensively provides for the right to education, has been interpreted as protecting the right to education even during armed conflict. For instance, the ESCR Committee alluded to this right when it declared in General Comment 13 that 'the obligation to protect requires state parties to take measures that prevent third parties from interfering with the enjoyment of the right to education'. 37 These third parties obviously include non-state armed groups. Also, paragraph 6 in part addresses 'certain interrelated and essential features of education' ${ }^{38}$ and, to this end, it identifies accessibility to education as an essential feature. Paragraph 6(b)(ii) on the subject of physical accessibility provides that 'education has to be within safe physical reach', which presupposes that the safety and protection of learners is a fundamental element of the protection of the right to education.

\subsubsection{Class-specific instruments}

In the UN system there are treaties that are class-specific. As such, these treaties apply primarily to members of a specific age, class or gender group. Some of these treaties also contain provisions on the right to education. The CRC, which applies to 'every human being below the age of eighteen years', 39 is a classic example of a treaty that is class-based. It provides for the right to education in article 28. Article 10 of CEDAW, a gender-based instrument, provides for equal rights to education for women, while article 24 of the CRPD provides for the right to education for persons living with disabilities.

\footnotetext{
33 Art 26(1).

34 Art 26(2).

$35 \mathrm{H}$ Espiell Significance of the Convention against Discrimination in Education (1960) (2005) 4.

36 As above.

37 General Comment 13 para 47.

38 ICRC 'Promoting and protecting education in situations of armed conflict' http:// www.icrc.org/eng/resources/documents/event/2014/01-10-humanitariumpromoting-protecting-education.htm (accessed 1 June 2014). 


\subsubsection{Protection of the right to education during armed conflict}

Primarily, the right to education in armed conflict is protected under the Fourth Geneva Convention and its two Protocols. ${ }^{40}$ The protection of education during armed conflict, however, is not limited to the Geneva Convention of 1949 and its Protocols. The same protection can be gleaned from other provisions in certain instruments relating to international humanitarian law, international human rights law and international criminal law which do not specifically address the right to education during armed conflict. For instance, article $8(2)(\mathrm{e})(\mathrm{iv})$ of the Rome Statute makes it a war crime to 'intentionally direct attacks against buildings dedicated to religion, education, art, science or charitable purposes ... provided they are not military objectives'. The events in Northern Nigeria readily come to mind when examined against this provision. The consistent attacks on schools, among other targets, by the Boko Haram sect reveal a gross violation of international criminal law, as contained in the provisions above. For its part, article 3(a) of the ILO Convention 182 on Child Labour outlaws the forced or compulsory recruitment of children for use in armed conflict. In Nigeria there are speculations that the secondary school students who were kidnapped from their hostel in April 2014 were being used as suicide bombers. ${ }^{41}$ This is a clear violation of the ILO Convention, more so because these students were abducted from their educational institution.

\subsection{African regional frameworks}

Unlike the situation at the UN level, Africa has no specific instrument that is wholly devoted to the right to education. However, there are provisions scattered in different instruments for the protection and guarantee of this right. Article 17 of the African Charter on Human and Peoples' Rights (African Charter) ${ }^{42}$ provides that 'every individual shall have the right to education'. 'Every individual' refers to people of

40 It is generally called the Law of Armed Conflict and it was adopted in 1949. Art 24 of the Convention provides that 'parties to the conflict shall take the necessary measures to ensure that children under fifteen, who are orphaned or are separated from their families as a result of the war, are not left to their own resources, and that their maintenance, the exercise of their religion and their education are facilitated in all circumstances'. This implies that even in circumstances of armed conflict, this provision envisages and requires that education must continue. Art 50 requires that parties to a conflict must 'facilitate the proper working of all institutions devoted to the care and education of children'. Art 94 provides that 'the education of children and young people shall be ensured; they shall be allowed to attend schools either within the place of internment or outside'. Also, in Protocol II to the Convention, relating to the Protection of Victims of Non-international Armed Conflict (1977), art 4 fundamentally guarantees that 'children receive an education'. Protocol 1 offers an interesting perspective in that it clearly dictates in art 52 that 'attacks shall be limited strictly to military objectives', and schools or educational facilities are not regarded as military objectives.

41 'Chibok girls fingered as suicide bombers' Vanguard 3 August 2014.

42 Adopted by the OAU in Kenya on 27 June 1981. 
all ages and, as such, this provision is interpreted as accommodating the child's right to education. Article 11 of the African Charter on the Rights and Welfare of the Child (African Children's Charter) ${ }^{43}$ provides that 'every child shall have the right to an education'. Article 12 of Protocol to the African Charter on Human and Peoples' Rights on the Rights of Women in Africa (African Women's Protocol) ${ }^{44}$ provides for the right to education and training for women and the girl child. Article 13 of the African Youth Charter ${ }^{45}$ provides that 'every young person shall have the right to education of good quality'.

In terms of the protection of education in times of armed conflict or emergency, the provisions of article 9(2)(b) of the African Union (AU) Convention for the Protection and Assistance of Internally Displaced Persons in Africa (2009) ${ }^{46}$ are provisions that may be interpreted to accommodate the protection of the right to education in cases of emergency. Article 9(2)(b) provides that state parties shall

provide internally-displaced persons to the fullest extent practicable and with the least possible delay, with adequate humanitarian assistance, which shall include food, water, shelter, medical care and other health services, sanitation, education, and any other necessary social services, and where appropriate, extend such assistance to local and host communities.

It must be noted, however, that the African Charter does not allow for derogation of any of its rights, even during emergency and armed conflict. The African Commission on Human and Peoples' Rights (African Commission) emphasised this in Commission Nationale des Droits de l'Homme et des Libertés $v$ Chad $^{47}$ as follows:

The African Charter, unlike other human rights instruments, does not allow for state parties to derogate from their treaty obligations during emergency situations. Thus, even a situation of civil war cannot be used as an excuse by the state violating or permitting violations of rights in the African Charter.

The implication of this is that the right to education, which is provided for in article 17 of the African Charter, cannot be derogated from in times of armed conflict. States owe a duty to continuously guarantee the right to education in times of armed conflict and other emergencies.

\subsection{Domestic legislative frameworks}

State parties to international treaties owe a duty to give effect to their international obligations through their national laws. ${ }^{48}$ In recognition

43 The adoption of the African Children's Charter in 1990 makes Africa the only continent in the world with a children-specific international instrument.

44 Adopted on 11 July 2003.

45 Adopted on 2 July 2006.

46 Adopted on 23 October 2009.

47 (2000) AHRLR 66 (ACHPR 1995) para 21.

48 UN Doc A/HRC/23/35 (2003), Report of the Special Rapporteur on the Right to Education, Kishore Singh. 
of this duty, Nigeria has not only ratified international treaties containing provisions on the right to education, but has also domesticated some international instruments in this respect, considering that Nigeria, being a dualist state, requires the domestication of foreign treaties before it is applicable in its national courts.

Traditionally, the interrelationship between national law and foreign treaties has always been discussed from a monist or dualist perspective. While there are debates as to the veracity of this interrelationship, a country's approach to the use of foreign laws has a great impact on the entire legal system. Also, 'the extent to which international human rights law becomes part of a country's domestic law correlates with the status international law enjoys under that country's domestic law' ${ }^{49}$ While monists perceive foreign law as a part of a single legal system and as such apply its provisions directly in their national courts, the dualists proceed otherwise. They posit that these two regimes are distinct and the inroad of foreign law into the state must be clearly provided for in the national laws. ${ }^{50}$ Nigeria is a clear example of a dualist state and, as such, it is 'the only dualist country in Africa to have formally incorporated an international human rights treaty verbatim, the African Charter on Human and Peoples' Rights'51 and, by so doing, the Charter became part of its national laws and thus is enforceable in Nigerian courts. In addition to the provisions of Chapter 4 of the 1999 Constitution, the provisions of the African Charter are now regarded as part of Nigeria's domestic laws. It was for this reason that the Nigerian Court of Appeal decided in IGP $\vee A N P P \&$ Others that 'the African Charter is 'part of the laws of Nigeria and ... courts must uphold $\mathrm{it}^{\prime} .52$

However, it should be noted that the domestication of the African Charter was in deference to section 12(1) of the 1999 Constitution, which provides that 'no treaty between the Federation and any other country shall have the force of law except to the extent to which any such treaty has been enacted into law by the National Assembly'. This implies that a treaty is without the force of law in Nigeria unless the National Assembly has domesticated it. The effect of this provision is that treaties have the same status as acts of parliament, in other words they are lower in status compared to the Nigerian Constitution. ${ }^{53}$ The Supreme Court has repeatedly harped on the importance of this

49 F Viljoen International human rights law in Africa (2012) 518.

50 H Kelsen The pure theory of law (1934) 328-347 trans M Knight (1967).

51 Killander 'The role of international law in human rights litigation in Africa' in EK Quansah \& W Binchy (eds) Judicial protection of human rights in Botswana: Emerging issues (2009) http://ssrn.com/abstract=1438556 (accessed 1 April 2014).

52 Appeal CA/A/193/M/05.

53 Sec 1(1) of the 1999 Constitution establishes the supremacy of the Constitution and subsec (3) provides that 'if any other law is inconsistent with the provisions of this Constitution, this Constitution shall prevail, and that other law shall to the extent of the inconsistency be void'. 
constitutional provision. In Oloruntoba Oju $v$ Dopemu, ${ }^{54}$ the Nigerian Supreme Court held that 'any provision of an existing law which is in conflict with the provisions of the 1999 Constitution must be pronounced void to the extent of such inconsistency'.

\subsubsection{Nigerian Constitution}

Chapter 4 of the Nigerian Constitution contains core fundamental rights. ${ }^{55}$ Curiously, the right to education is not included as one of these core fundamental rights. The right to education, as well as other socio-economic rights, rather are contained in Chapter 2 of the Constitution and are referred to as 'fundamental objectives and principles of state policy'. The provisions in Chapter 2 are nonjusticiable ${ }^{56}$ and, as such, citizens cannot legally hold the government accountable for a violation of the right to education and other socioeconomic rights solely on the basis of the Constitution.

However, in Odafe \& Others $v$ Attorney-General \& Others ${ }^{57}$ and Gbemre $v$ Shell Petroleum Development Company Nigeria Limited \& Others $^{58}$ Nigerian courts held that a declaration of the socio-economic rights violations sought by the applicants in the two cases ${ }^{59}$ succeeded in spite of the fact that these rights are non-justiciable in the context of the Nigerian Constitution.

Additionally, the right to education was specifically held to be enforceable and thus justiciable by the Nigerian Federal High Court on 1 March 2017. In the case of Legal Defence and Assistance Project $(L E D A P) \vee$ The Federal Ministry of Education ${ }^{60}$ the Court held that the combined effect of section 18(3) of the Nigerian Constitution and section 1 of the Compulsory Free Universal Basic Education Act of 2004 was that the right to basic education is enforceable in Nigeria. ${ }^{61}$

54 (2008) All FWLR Part 411, 810

55 Dada (n 32 above) 43.

$56 \operatorname{Sec} 6(6)(c)$ of the Constitution of the Federal Republic of Nigeria.

57 (2004) AHRLR 205 (NgHC 2004).

58 (2005) AHRLR 151 ( NgHC 2005).

59 The right to health in art 16 and the right to a satisfactory environment in art 24 respectively were the crux of the matter in the two cases, and the Nigerian High Court allowed the invocation and justiciability of these rights solely on account of the provisions of the African Charter.

60 Suit $\mathrm{FHC} / \mathrm{ABJ} / \mathrm{CS} / 978 / 15$.

61 'In that case, the Plaintiff contended that although Section $6(6)(c)$ renders the provisions of Chapter 2 of the 1999 Constitution unenforceable, however, once a legislation is enacted to give legal effect to any of the provisions of the said Chapter 2 of the 1999 Constitution, the right contained in such provisions become enforceable notwithstanding section $6(6)(c)$ of the Constitution. The Plaintiffs further contended that having enacted the Compulsory, Free Universal Basic Education Act, 2004, the National Assembly has given legal effect to rights to free universal primary education and free junior secondary education for every Nigerian child in line with the joint provisions of Section 2 and 3 of the Compulsory, Free Universal Basic Education Act, 2004 as well as Section 18(3)(a\} of the 1999 Constitution.' See Y Adegboye 'The right to education under Nigerian law' https://www.lawyard.ng/the-right-to-education-under-nigerian-law-by-yinkaadegboye/ (accessed 30 April 2018). 
Furthermore, in The Registered Trustees of the Socio-Economic Rights Accountability Project $v$ the Federal Republic of Nigeria ${ }^{62}$ the ECOWAS Court of Justice held that the right to education was directly enforceable. 63

The political history of Nigeria has had a significant impact on its legal system considering that Nigeria domesticated the African Charter at a time of military rule and subsequent suspension of the Constitution. ${ }^{64}$ The ratified African Charter, alongside Chapter 4 of the Nigerian Constitution, has been useful in the protection of the rights of citizens. While the Constitution has been suspended severally, the operation of the African Charter 'has never been suspended, leaving the door open for their judicial application' 65 Thus, in the case of Garba $v$ Attorney-General of Lagos State, ${ }^{66}$ the Court held that 'even if [any] aspect of our Constitution is suspended or ousted by any provision of our local law, the international aspect of it cannot unilaterally be abrogated'. The Court proceeded to rely on the provisions of the African Charter to assume jurisdiction over the matter. ${ }^{67}$

\subsubsection{Compulsory Free Universal Basic Education Act of 2004}

As the name suggests, this Act seeks to make the basic education of a child not only compulsory but also free and accessible. The Act places the duty of providing basic education on all state governments in Nigeria, and clearly provides that 'the Federal Government's intervention under this Act shall only be an assistance to the states and local governments in Nigeria' ${ }^{68}$ It further makes it a crime for parents to refuse to send their wards and children to school. It seeks the co-operation of parents in the implementation of the Act.

After the brief analysis of the provisions relating to the child's right to education and its protection during emergencies at the international, regional and domestic levels, it is necessary to focus on the Boko Haram sect in Northern Nigeria. The next sections consider the history, ideology, activities and impact of the sect on children's rights to education.

\footnotetext{
62 Suit ECW/CCJ/APP/0808 delivered on 27 October 2009.

63 See A Skelton \& S Kamga 'Broken promises: Constitutional litigation for free primary education in Swaziland' (2017) 61 Journal of African Law 434.

64 Nigeria ratified the African Charter on 22 June 1983.

65 Viljoen (n 49 above) 534.

66 Suit ID/599M/91 (31 October 1991).

67 F Viljoen 'Application of the African Charter on Human and Peoples' Rights by domestic courts in Africa' (1999) 43 Journal of African Law 1.

68 PA Arhedo et al 'School counsellors' roles in the implementation of Universal Basic Education (UBE) scheme in Nigeria' (2009) 2 Edo Journal of Counselling 60.
} 


\section{Activities of Boko Haram and impact on education}

By their nature armed conflicts have catastrophic and far-reaching consequences. Considering the fact that the impact of war and armed conflict extends beyond the period of the conflict itself, it is not difficult to understand why war is described as 'development in reverse'.69 The capacity of conflicts to reverse gains of many years is well known, irrespective of whether the conflict continues for a lengthy period or not. The impact is graver and more severe in African countries, where the capacity to withstand the effect of conflict is stifled by mass poverty and underdevelopment. ${ }^{70}$

While the above position generally is true, it appears that the sector most often affected by the reverse in gains and development as a consequence of armed conflict is the educational sector. 'Armed conflict is destroying not just school infrastructure, but also the hopes and ambitions of a whole generation of children. ${ }^{71}$ The disruptive impact of armed conflict on education 'represents one of the greatest developmental setbacks for countries affected by conflict' ${ }^{72}$ The long and short-term effects of the disruptive impact of armed conflicts on education are the focus of this article. It focuses on the activities of Boko Haram as an example of an armed group waging modern armed conflict against a state. It is evident that attacks on schools, educational infrastructures, educators and learners are fast becoming a reality of modern conflict, ${ }^{73}$ and the article attempts a chronological outline of these forms of attacks and their overall effect on the educational system.

\subsection{History and ideology of Boko Haram}

In an attempt to use Boko Haram as an example of a modern armed group waging a modern armed conflict, this study examines its history and ideology as necessary determinants of its activities.

\subsubsection{History of the sect}

The precise date of Boko Haram's emergence in the polity and political life of Nigeria is mired in controversy. ${ }^{74}$ This is so because violent armed groups by their nature often originate in secrecy and

69 P Collier The bottom billion: Why the poorest countries are failing and what can be done about it (2007).

70 UNESCO commissioned report titled 'The hidden crisis: Armed conflict and education' (2011) 131 http://unesdoc.unesco.org/images/0019/001907/1907 43e.pdf (accessed 10 August 2014).

71 As above.

72 UN Doc A/51/306 (1996) 'Promotion and protection of the rights of children: Impact of armed conflict on children' para 186.

73 M Wessel \& R Hirtum 'Schools as tactical targets in conflict: What the case of Nepal can teach us' (2013) 57 Comparative Education Review 1.

74 J Adibe 'What do we really know about Boko Haram' in I Mantzikos (ed) Boko Haram: Anatomy of a crisis (2013) 11. 
the usual manner of learning about them is through unreliable media accounts. ${ }^{75}$ While most media accounts trace its origin back to 2002 when its activities became known, particularly with the emergence of Mohammed Yusuf as its leader, other sources in Nigerian security circles date the origin back to 1995. The group was started as a nonviolent religious sect known as Ahlulsunna wal'jama'ah hijra in the University of Maiduguri in Borno State. ${ }^{76}$ It only began to show violent tendencies when the founding leader; Abubakar Lawan, exited the sect and Yusuf became its new leader in 2002. ${ }^{77}$

From 2002 to date the sect has operated under various names that include Muhajirun, Yusufiyyah, Nigerian Taliban, Boko Haram and Jama'atu Ahlissunnah lidda'awati wal Jihad. ${ }^{78}$ The current appellation, Boko Haram, is a Hausa language designation that literally translates to 'Western education is forbidden', and this is a pointer to one of the driving objectives of the group. Its official name, however, is Jama'atu Ahlissunnah lidda'awati wal Jihad, which in English means 'People committed to the propagation of the prophet's teachings and jihad'. ${ }^{79}$ In 2004 the sect migrated from Borno State to Yobe State and established a 'kingdom' for itself. This 'kingdom' was called Afghanistan. ${ }^{80}$ From this 'kingdom', the sect planned to export the imposition of Islamic rule on Northern Nigeria, as a response to what it calls the corrupt establishment known as the Nigerian state. According to Yusuf, its goal was that 'a Shari'a state should be established in Nigeria, and if possible all over the world, through preaching the faith $\left(D a^{\prime} w a h\right)^{\prime}{ }^{81}$ However, Yusuf was captured and extra-judicially killed in $2009^{8 \dot{2}}$ alongside more than 1000 members of the sect in a four-day battle with Nigerian security forces. ${ }^{83}$ Many believe that Yusuf's extra-judicial killing is the major factor for the escalation of the Boko Haram insurgency. Indeed, one of the immediate consequences was the fragmentation of the sect and the

75 FC Onuoha 'Boko Haram: Nigeria's extremist Islamic sect' (2012) 2, Report commissioned by Aljazeera Centre for Studies.

76 As above.

77 F Onuoha 'Understanding Boko Haram's attacks on telecommunication infrastructure' in Mantzikos (n 80 above) 18.

78 Onuoha (n 77 above). See also R Loimeier 'Boko Haram: The development of a militant religious movement in Nigeria' (2012) 47 Africa Spectrum 2-3.

79 See generally A Murtada Boko Haram in Nigeria: Its beginnings, principles and activities in Nigeria (2013).

80 O Patrick \& O Felix 'Effect of Boko Haram on school attendance in Northern Nigeria' (2013) 1 British Journal of Education 1-9.

81 'Boko Haram' in 'Almanac of Islamism; American Foreign Policy Council Report August 2014' http://almanac.afpc.org/boko-haram (accessed 3 October 2014). See also JJF Forest 'Confronting the terrorism of Boko Haram in Nigeria' (2012) Joint Special Operations University (JSOU) Report 12-5.

82 E Ojo 'Boko Haram: Nigeria's extra-judicial state' (2010) 12 Journal of Sustainable Development in Africa 2. See also D Agbiboa 'Peace at daggers drawn? Boko Haram and the state of emergency in Nigeria' (2014) 37 Studies in Conflict and Terrorism 41-67.

83 D Agbiboa 'Why Boko Haram exists: The relative deprivation perspective' (2013) 3 African Conflict and Peacebuilding Review 144-157. 
enthronement of the hawks within the sect, led by Abubakar Shekau, an erstwhile deputy of Yusuf. ${ }^{84}$

In July 2010, one year after the death of Yusuf, Shekau announced that he had assumed leadership of the sect. This was a turning point, as it became a rebranded violent sect. ${ }^{85}$ Scholars have described this turn as one 'from peaceful origin to violent extremism' ${ }^{86}$ While Yusuf had sought to establish his 'Islamic State' through preaching the faith, Shekau opted for a more violent means of jihad. ${ }^{8}$

Shekau believes that Boko Haram cannot negotiate any final solution to the conflict with the Nigerian government until Boko Haram has created an Islamic state or Nigeria adopts a Boko Haram-approved version of Shari'a law.

It is for this reason that the new and current official name, Jama'atu Ahlissunnah lidda'awati wal Jihad, incorporates Yusuf's idea of Da'wah or preaching the faith, and Shekau's concept of Jihad. Since 2009, the group has carried out more than 1000 attacks that have led to the deaths of thousands of people. ${ }^{88}$ It has also evolved considerably from a local threat to a regional menace, ${ }^{89}$ maintaining camps in several countries, ${ }^{90}$ receiving funds from external sources and being rumoured to have links with Al-Qaeda, the Afghan Taliban, the Somalian Al Shabbab and other international terrorist organisations. ${ }^{91}$

84 Several splinter groups have emerged from the fragmented Boko Haram, the most prominent being the Ansaru group which was founded in 2011 by Abubakar Adam Kambar. He was killed in 2012 by Nigerian security forces and was replaced by Khalid Barnawi who is rumoured to have linked the group with Al-Qaeda in the Islamic Maghreb (AQIM). The Ansaru is said to be a more professional group consisting of trained combatants, unlike the mainstream Boko Haram that thrives on recruiting disgruntled and untrained elements in society. Ansaru regularly criticises Shekau and his group for their wanton destruction and killings of innocent Muslims. See generally M Perouse de Montclos 'Nigeria's interminable insurgency? Addressing the Boko Haram crisis' A Chatham House Research Paper, September 2014.

85 'Curbing violence in Nigeria (II): The Boko Haram insurgency' International Crisis Group Report 216, April 2014, http://www.crisisgroup.org/ /media/Files/africa/ west-africa/nigeria/216-curbing-violence-in-nigeria-ii-the-boko-haram-insurgency. pdf (accessed 3 October 2014).

86 J Barna 'Insecurity in context: The rise of Boko Haram in Nigeria' http:// www.europarl.europa.eu/RegData/etudes/note/join/2014/536393/EXPO-AFET_N T(2014)536393_EN.pdf (accessed 4 October 2014).

87 n 85 above.

88 http://www.romereports.com/pg157728-human-rights-watch-releases-boko-hara m-death-toll-in-2014-en (accessed 7 October 2014).

89 JP Pham 'Boko Haram's evolving threat' (2012) 20 Africa Security Brief 1-7.

90 Barna (n 86 above).

91 Al Ajayi 'Boko Haram and terrorism in Nigeria: Exploratory and explanatory notes (2012) 1 Global Advanced Research Journal of History, Political Science and International Relations 103-107. See also SM Gourley 'Linkages between Boko Haram and al Qaeda: A potential deadly synergy' (2012) 3 Global Security Studies 1-14. Also see generally $V$ Thomson 'Boko Haram and Islamic fundamentalism in Nigeria' (2012) 3 Global Securities Studies 46-60. 
Its members traverse many national boundaries in the West African sub-region, carrying out attacks at will. ${ }^{92}$

\subsubsection{Ideology of the sect}

The sect's ideology or philosophy is founded upon the practice of orthodox or conservative Islam and 'an attempt at imposing a variant of Islamic religious ideology on a secular state' ${ }^{93}$ Conservative Islam, by its very nature, abhors Western civilisation and all its paraphernalia. ${ }^{94}$ Education is one of these paraphernalia and, as such, this brand of Islamism abhors Western education. The current political structure in Nigeria is also seen as an offshoot of Westernisation, hence the call for the abolition of the present governance structure and the imposition of Shari'a law. The sect calls for the abolition of 'a Western way of life, democratic institutions, constitutional laws and the institutions of the Nigerian state' ${ }^{95}$ The sect's consistent attacks on Christians and their places of worship also speak volumes about their abhorrence of the Christian faith, which they perceive as an offshoot of Western civilisation. This ideology also explains why it directs its attacks on government buildings and officials, as well as civilians that are caught in between. As such, the sect seeks the overthrow of the current Nigerian governance structure and the imposition of Shari'a law. It seeks to do this through a combination of Dawa'a (preaching the faith) and Jihad (waging a holy war).

The sect also believes that a true Islamic state ought to be established out of the ruins of the destruction of the present Nigerian state. This is why it migrated several thousands of its members to Yobe State in 2004 to establish its kingdom. ${ }^{96}$ Non-members are considered infidels, unbelievers or wrongdoers. ${ }^{97}$ Its main guiding principles are abhorrence of democracy as it conflicts with Islam; the prohibition of studying in educational systems as it opposes Islamic education; and the rejection of employment under the current Nigerian state. ${ }^{98}$

92 UNESCO (n 70 above) 5-6.

93 A Adesoji 'The Boko Haram uprising and Islamic revivalism in Nigeria' (2010) 45 African Spectrum 95. See also M Opeloye \& FISN 'The Boko Haram insurgency in Nigeria: A critical study of the movement's ideological posture and implications' (2012) 51 Doi: 10.7763/IPEDR 38 172-181.

94 E Onyebuchi \& C Chigozie 'Islamic fundamentalism and the problem of insecurity in Nigeria: The Boko Haram phenomenon' (2013) 15 IOSR Journal of Humanities and Social Science (IOSR-JHSS) 43-53.

95 As above.

96 Patrick \& Felix (n 80 above).

97 Onuoha (n 77 above).

98 Murtada (n 79 above) 16-18. 
The importance of examining the sect's origin and ideologies is to be able to properly contextualise its activities. As a modern armed group, Boko Haram, like the Afghan Taleban, ${ }^{99}$ has consistently attacked schools and learners, simply because of their connection to education, and the abduction of 234 schoolgirls on 14 April 2014 is in furtherance of its ideologies. The next section focuses on the impact of modern armed conflicts on the realisation of the right to education.

\subsection{Impact of modern armed conflicts on the right to education}

This section examines the precise impact that activities of armed groups have on the realisation of the right to education. It does this by examining the changing nature of armed conflict, in order to justify the claim that Boko Haram is a modern armed group. It further chronicles the effect of their activities and attacks on the realisation of the right to education.

The traditional notion of war is the idea of armed conflict between two or more states or, even better, fighting between armies of different states, usually after a formal declaration of hostility or war. Classic examples are World Wars I and II, and almost all the wars before then. In those wars, attacks are directed at military targets, battlegrounds that are far removed from the civilian population. While not always respected, such wars had strict rules that govern them, and the parties in the conflict were always aware of these rules. A peculiar characteristic of these rules was that they changed from time to time. For instance, there was a time when hoisting a white flag signified surrender, and combatants not only ceased attacks at dusk, but they also surrendered to the opposing forces if a key leader was captured. Parties strive hard to respect these codes and their desecration, particularly during World War II, accounted for the adoption of codified international humanitarian and human rights law rules. 100

One of the consequences of these codifications was that the term 'war' was replaced by the term 'armed conflict', which is loosely defined as the use of arms, in a conflict, between two or more parties. ${ }^{101}$ The difference is that while war used to be construed as a military engagement between two or more states, armed conflict has a wider scope, as there is no requirement for the parties to be states, properly so called. Armed conflict can be either international or noninternational. International armed conflict is strictly between states,

99 The attacks by the Taleban on Malala Yousufzai and other children in Pakistan and Afghanistan are reminders of the plight of children in the hands of such armed groups; http://www.bbc.com/news/world-asia-19882799 (accessed 7 October 2014).

100 See generally IBCR Children and armed conflict: A guide to international humanitarian and human rights law (2010).

101 J Mrazek 'Armed conflicts and the use of force' (2010) 1 Czech Yearbook of Public and Private International Law 95. 
while non-international armed conflict is between states and non-state entities. $^{102}$

Some distinguishing characteristics of this contemporary armed conflict are intentional attacks on civilian population; the prolonged duration of the conflict; a loose military command structure; a link between armed groups and criminal networks; unclear and nebulous motivation for fighting; easier access to small arms; the use of terror tactics; as well as building the group around a leader. ${ }^{103}$

\subsection{How Boko Haram's attacks fit into the description of modern armed conflict}

Whether one calls it 'informal war',104 'the new war', 105 'contemporary armed conflict', 106 'asymmetry warfare', 107 'irregular or hybrid warfare'108 or even 'terrorism', 109 one golden thread runs through them all, namely, the fact that they refer to armed conflicts between a state and non-state entities, with the latter adopting various unconventional approaches to the warfare. ${ }^{110}$ Such approaches include guerilla tactics that involve surprise attacks in places that are not declared battlegrounds or war zones. In this respect the targets usually are civilians and/or infrastructures that are generally meant for use by the civil populace. This presupposes that there is a difference between these types of conflicts and other types where one state wages war against another, and the targets in such conventional wars usually are military targets. The death of civilians is classified as collateral damage as they really are exceptions to the rule. $^{111}$

Kaldor identifies certain other distinguishing characteristics of these new wars. She calls them globalised wars that 'involve the fragmentation and decentralisation of the state'. ${ }^{112}$ The recent bold attacks by Boko Haram and annexation of territories within the

102 See generally N Balendra 'Defining armed conflict' (2008) 29 Cardozo Law Review 2461.

103 M Kaldor New and old wars (2007).

104 S Metz Armed conflict in the 21st century: The information revolution and postmodern warfare (2000) xii.

105 Kaldor (n 103 above).

106 IBCR (n 100 above) 31.

107 See generally D Buffaloe 'Defining asymmetric warfare' (2006) 58 The Land Warfare Papers.

108 F Hoffman 'Hybrid warfare and challenges' (2009) 52 Joint Force Quarterly 3.

109 G Chaliand \& A Blin (eds) The history of terrorism from antiquity to Al Qaeda trans E Schneider et al (2007).

110 K Coons \& G Harned 'Irregular warfare is warfare' (2009) 1 Joint Force Quarterly 97.

111 IBCR (n 100 above).

112 Kaldor (n 103 above) 95. 
territorial enclave of Nigeria ${ }^{113}$ fit into this characteristic of the new war, as described by Kaldor. Furthermore, these groups often receive external support and their attacks are directed against civilians, among other targets. Also, the wars are political conflicts that are often waged as a result of underlying economic dissatisfaction. Boko Haram has often claimed that their agitation is against the corruption and economic neglect by the northern elites and the Nigerian government. Other noticeable characteristics are the presence of splinter groups, 'autonomous groups of armed men centred around a leader', the use of child soldiers and foreign mercenaries as well as a unique pattern of violence with the ultimate goal of spreading fear and terror amongst the populace. It is necessary to state that all these characteristics are apparent with Boko Haram and, as such, it is appropriate to conclude that Boko Haram fits into the description of a modern armed group, waging the 'new war'.

\section{Impact of modern armed conflict on education}

In various ways conflicts affect education in manners that are often intractable. The death of teachers and students as well as the destruction of educational facilities are some of the gravest impacts that armed conflicts have on education. An immediate observation is that apart from making schools their primary targets for attacks, the Boko Haram ideological opposition to schooling, particularly that of girls, is a further reason for the attacks. Needless to say, these attacks, while limiting access to school, serve to increase the absence of teachers and students from school. ${ }^{114}$ Conflicts also increase the tendency of dropping out of school, the military recruitment of child soldiers and also economic hardship. The quality and standard of education usually are lowered during armed conflict and the shortening or permanent disruption of the academic calendar evidences this. ${ }^{115}$ Conflicts further widen the economic inequality in society, thus ensuring that the need to drop out of school is heightened for the poorer section of the community.

The peculiar circumstances of the girl child deserves to be mentioned. The situation in Northern Nigeria has a grave impact on the plight of the girl child. Conflicts serve to exacerbate gender disparities as most parents now keep their girl children at home. The dangers of sexual exploitation, rape and early pregnancy are rife. ${ }^{116}$ This is a dimension of the general low rate of enrolment in schools in

113 'Boko Haram annexes town' The Times 25 August 2014 http://www.the times.co.uk/tto/news/world/africa/article4185850.ece (accessed 7 October 2014).

114 UNESCO Doc 2011/ED/EFA/MRT/PI/50 'The quantitative impact of conflict on education' Think piece prepared for the Education for All Global Monitoring Report 2011.

115 O Shemyakina 'The effect of armed conflict on accumulation of schooling: Results from Tajikistan' (2011) 95 Journal of Development Economics Elsevier 186. 
places affected by conflict. The school enrolment rate has reduced radically and is on the decline in Northern Nigeria. This is a region that characteristically has the lowest percentage of school enrolment in Nigeria and, consequently, as reported by the UN, the highest number of out-of-school children in the world. ${ }^{117}$ This is directly tied to poor performance in education and the unequal literacy rate between the northern and southern parts of Nigeria. ${ }^{118}$ The overarching effect of armed conflict is that it drains funds and financial resources that should have been ploughed into human development through education. In states such as Nigeria, money is devoted to procuring military equipment to wage war during the duration of the conflict. After the conflict, money is also committed to rebuilding society. These funds can judiciously be used to promote and provide education in the absence of conflict. The situation is more disturbing in most African countries where powerful individuals benefit from the large amounts of money budgeted for the prosecution of the war, and they consequently promote these wars.

To recap, armed conflict impacts on education by reducing the standard of education; by the destruction of educational facilities; the promotion of inequality; the exposure of learners and educators to attacks, rape and other sexual violence; the exposure of children to abductions and kidnapping and recruitment as child soldiers; by reinforcing poverty; causing a diversion of finance from education to military expenditure; and large-scale internal displacement.

After a thorough examination of the impact of armed conflict on education, and in light of the legal frameworks discussed earlier, it is appropriate to ask whether these frameworks are sufficient, adequate or efficacious in protecting the right to education during armed conflict.

\section{Accountability debate}

As noted earlier, the need to revisit the accountability debate of nonstate armed groups has arisen because of renewed attacks on education and educational facilities around the globe. This is further compounded by the fact that there is no agreement on a clear approach towards bringing such groups to book under the present frameworks in international law.

116 Save the Children UK 'Forgotten casualties of war: Girls in armed conflict' (2005) https://childhub.org/en/child-protection-online-library/save-children-uk-2005forgotten-casualties-war-girls-armed-conflict (accessed 30 June 2018).

117 A Abdulmalik 'Shocking: Nigeria holds world record in number of children out of school' Premium Times 11 June 2013.

118 Patrick \& Felix (n 80 above). See also AS Ekereke 'The effects of Boko Haram insurgency and the school system: A case study of selected states in Northern Nigeria' (2013) Science Journal of Sociology and Anthropology 1. 


\subsection{An investigation into the efficacy of the existing legal frameworks for protection of the right to education during armed conflict}

Given the international, regional and domestic frameworks discussed earlier, it is appropriate to ask whether these frameworks are sufficient, adequate or efficacious in protecting the right to education during armed conflict. Clapham argues that although non-state actors are among the greatest violators of human rights, ${ }^{119}$ there are no treaty obligations under international human rights law to hold them accountable. 'The universal and regional human rights instruments are all formulated in terms of states' obligations. ${ }^{\prime 20}$ This is without prejudice to the fact that 'international humanitarian law applies to each party to a non-international armed conflict and that each party to the conflict must respect and ensure respect for international humanitarian law'. ${ }^{121}$ For its part, international criminal law imposes individual criminal liability upon those who commit international crimes. ${ }^{122}$ These crimes are those referred to in article 5 of the Rome Statute. They include genocide, crimes against humanity, war crimes and the crimes of aggression. These are crimes that are generally committed in the context of armed conflict. The overall effect of these limited treaty obligations that are not applicable to non-state actors is a weakening of the frameworks for addressing the challenges to education during armed conflict.

For one, Nigeria's efforts at holding Boko Haram accountable has been everything but impressive. A major limitation of the legal system in Nigeria is that 'criminal law is the responsibility of each state in the federation as it is not in the exclusive and concurrent legislative list'. $^{123}$ The implication of this is that 'every state in Nigeria has the power to regulate the administration of criminal justice in its jurisdiction'. ${ }^{124}$ Therefore, it has been argued that this individualistic

119 A Clapham 'Human rights obligations of non-state actors in conflict situations' (2006) 88 International Review of the Red Cross 863; see also O Bangerter 'Talking to armed groups' (2011) Forced Migration Review 37.

120 Y Ronen 'Human rights obligations of territorial non-state actors' (2013) 46 Cornell International Law Journal 35.

121 A Cassese 'The status of rebels under the 1977 Geneva Protocol on NonInternational Armed Conflict' (1981) 30 International and Comparative Law Quarterly 424, also see UNSC Resolution 1214 (1998), 8 December 1998, para12; $\mathrm{T}$ Pfanner 'Various mechanisms and approaches for implementing international humanitarian law and protecting and assisting war victims' (2009) 874 International Review of the Red Cross 279 281. See also K Hausler et al Protecting education in insecurity and armed conflict: An international law handbook (2012) 44. See also J Kleffner 'The applicability of international humanitarian law to organized armed groups' (2011) 93 International Review of the Red Cross 444.

122 R Vark 'Superior responsibility' http://www.ksk.edu.ee/wp-content/uploads/2012/ 12/KVUOA_Toimetised_15_7_Vark.pdf (accessed 27 June 2014).

123 B Olugbuo 'Acceptance of international criminal justice in Nigeria: Legal compliance, myth or reality?' International Nuremberg Principles Academy https:// www.nurembergacademy.org/fileadmin/media/pdf/acceptance/Nigeria.pdf (accessed 30 April 2018).

124 As above. 
approach has affected the effective national implementation of the Rome Statute and, consequently, the acceptance of international criminal justice. ${ }^{125}$ This has undoubtedly impacted on Nigeria's ability to hold members of the Boko Haram sect accountable.

Nigeria is a party to the Rome Statute. The Prosecutor of the ICC has identified six possible cases of crimes against humanity and war crimes committed by Boko Haram in the northeast insurgency. ${ }^{126}$ Accordingly, individual members of Boko Haram can be charged with war crimes or any of the crimes in the ICC Statute. While this does not hold the entire armed group accountable, it must be stressed that this form of accountability, however inadequate, could serve as a deterrent as this is one of the overall goals of international criminal law, in general, and the ICC, in particular. ${ }^{127}$

It must also be understood that even the rules of international humanitarian law that are generally applicable to states and non-state actors have their implementation mechanisms still 'mainly geared towards states'.128 While international humanitarian and human rights law are mainly state-based, the reality of armed conflict today is less and less state-centred. The overall outcome is that international law, as presently conceived, does little or nothing to prevent the occurrence of armed conflicts, in so far as it relates to the activities of armed groups. 'It deals with armed groups, not to regulate [or forestall] their activities, but to fight them, to calm the situations they create, or to manage the consequences of their disruptive existence. $^{129}$ In this respect, it is argued that a more effective framework is one that strives to forestall the occurrence of armed conflict, thereby helping to avoid their disruptive impact on education. The present frameworks can best be described as medicine after death and, as such, they only attempt to offer solutions after the problems of emergencies and armed conflict have been created. The Nigerian government's efforts at combating the Boko Haram insurgency reflects the same approach.

Further, as established earlier, international human rights law has no mechanism for holding armed groups accountable, as its rules are state-based and are focused on states. The reality of modern warfare, however, is that more conflicts are caused and perpetrated by armed groups fighting against themselves or against the armed forces of a state or states. Boko Haram, for example, has been involved in military

125 As above.

126 Human Rights Watch 'They set the classrooms on fire' (2016) 81 https:// www.hrw.org/sites/default/files/report_pdf/nigeria0416web.pdf (accessed 30 April 2018).

127 C Hillebrecht 'The deterrent effects of the International Criminal Court: Evidence from Libya' (2016) 42 International Interactions 616.

128 M Sassoli 'Taking armed groups seriously: Ways to improve their compliance with international humanitarian law' (2010) 1 International Humanitarian Legal Studies 5.

129 Z Dabone 'International law: armed groups in a state-centric system' (2011) 93 International Review of the Red Cross 882. 
attacks against the armed forces of Nigeria, Cameroon, Chad and even Niger. Hence, the argument is that since armed conflicts affect human rights and their actions violate international human rights law, armed groups should be held accountable under that particular body of law. Their acts often are a direct violation of one or other right. In this instance their actions violate the rights to education. In so far as their actions violate international obligations under these collective bodies of law, in the same manner they should without exception be held accountable under all these bodies of law.

Lastly, as argued earlier, the nature of warfare has changed. It is not the same warfare that was envisaged in the 1960s and 1970s, when these rules of international law on armed conflict were formulated, that is still being waged in the twenty-first century. However, international law has not evolved in a corresponding fashion to appropriately address the challenges brought about by the new wars. ${ }^{130}$ Most of the obligations under international humanitarian law were formulated with the understanding that war was primarily between two or more states. The reality today is different. This has accounted for the weakness of international law to hold faceless armed groups accountable for the violation of the right to education.

A pertinent question that has arisen relates to what impact a change in the framework will have on armed groups such as Boko Haram, that clearly have a disregard for international and domestic law in the first place. The proper response is that international law and all its branches, including international criminal law, continues to grow and expand. As such, a strengthening of the existing legal frameworks may not end all the complications attached to the violations of the child's rights to education during armed conflicts or other emergencies. It will, however, serve the purpose of bringing humanity closer to the goal of ending impunity and punishing crimes of atrocity.

130 In the last few decades, the term 'armed conflict' has replaced the concept of war. The present rules of international humanitarian law were formulated to address the challenges of war and, thus, its limitations in addressing the new war or armed conflict as it is properly called. The term obviously is broader than the concept of war, and it accommodated the fluidity and fragmentation that is a major characteristic of modern armed conflict. The deliberate targeting of civilians and places of education is an offshoot of these 'new wars'. One-sided violence, terrorism, asymmetric conflict and other noticeable characteristics are the hallmark of the new war. The players often are faceless and the hierarchical structure of the armed group often is unknown to outsiders. In fact, there often is a strong link between the armed groups and transnational criminal networks, often acting as mercenaries. The delineation are not as clear as the existing frameworks envisage. See generally IBCR 'Children and armed conflict: A guide to international humanitarian law' (2010) www.ibcr.org. See also Y Dinstein War, aggression and self-defence (2001); E Stepanova 'Trends in armed conflicts: Onesided violence against civilians' (2009) Stockholm International Peace Research Institute Yearbook 39. 


\subsection{Recommendations on accountability}

The weakness of international law to effectively respond to the 'new war' readily accounts for different scholars' positions and recommendations on the issue. While arguing that non-state actors are among the greatest violators of human rights, Clapham suggests that they should also be held accountable under applicable rules of international law. He admits that 'the threats posed by non-state actors is of increasing concern', 131 hence the need for accountability. He goes further by recommending approaches towards holding such non-state actors accountable as they are all 'expected to comply with principles of international human rights law'. ${ }^{132}$ In his opinion, there have been times when parties to a conflict entered into some sort of written agreement, not only to respect the rules of the conflict but also to outrightly uphold and respect human rights during the period of the conflict and thereafter. His argument is that such approaches can be recalled. ${ }^{133}$ This helps to put the protection of the rights of all parties, including those of civilians, at the centre of the conflict. It also helps to extend the obligations of the armed groups beyond the period of the armed conflict, thus ensuring accountability even after the timeline of the conflict.

Sassoli advocates approaches that involve educating armed groups on the provisions of international law, allowing and encouraging them to commit to respect international humanitarian law and also assisting them to implement the law. He favours self-reporting and external reporting through the use of UN Charter and treaty-based human rights mechanisms as viable approaches towards accountability. In a more controversial submission, he entertains the idea of establishing a body of experts by states for the periodic review of compliance to international law by armed groups. However, he was quick to point out the danger of states politicising such a body, and this remains a fundamental flaw in the idea. Finally, he suggests the establishment of an audit body by armed groups themselves. ${ }^{\top 34}$

For his part Andreopolous recommends engagement practices and activities that include 'constructive dialogue, adoption of codes of conduct, shaming through media attention, sanctions, accountability mechanisms and UN Security Council-authorised enforcement measures'. ${ }^{135}$

Specifically in relation to Boko Haram, Nigeria deserves to improve its response to the insurgency. Given the earlier identified lapse in its legal system, especially the need to domesticate all international treaties, there is a dire need for the country to accelerate its efforts in domesticating the Rome Statute. A draft of the Crimes Against

131 Clapham (n 119 above).

132 As above.

133 Clapham (n 119 above) 493.

134 Sassoli (n 128 above) 30-32.

135 Andrepolous (n 2 above) 142. 
Humanity, War Crimes, Genocide and Related Offences Bill, 2012 has already been submitted to the National Assembly for translation into national law. Domesticating the Rome Statute will strengthen Nigeria's legal framework in order to properly respond to the insurgency in accordance with its obligations under various international treaties and agreements.

Again, the inability of the Nigerian government to impartially investigate and appropriately prosecute Boko Haram leaders has become inexcusable. Under its current flawed legal system, Nigeria can indeed still hold the members of the group accountable. The failure to achieve this needs to be addressed. While the President has promised to grant amnesty to any member of the sect who willingly surrenders and lays down his arms, it is recommended that this approach should not jeopardise the need for justice through the country's legal system.

\section{Conclusion}

The article has discussed the accountability debate that surrounds the activities of non-state actors and their impact on the realisation of the child's right to education. It has also examined the legal framework for the protection of the right to education during emergencies and armed conflicts. It thereafter focused on Boko Haram as an example of a non-state armed group. In this respect it considered the sect's history and its ideological beliefs and sought to show that their activities are a result of their ideologies. It thereafter delved into the accountability debate and suggested various approaches towards holding faceless armed groups accountable for rights violations, generally, and the violation of the child's right to education, in particular. It found that there is a need to strengthen the domestic and international frameworks for holding non-state actors accountable for rights violations, in general, and the violation of the right to education, in particular. This need has arisen because of the changing nature of warfare. As such, the need for a continuous adaptation of international frameworks that adequately respond to the changing nature of warfare cannot be overemphasised. 